\title{
Commentary Are biologics more effective than classical disease-modifying antirheumatic drugs?
}

\author{
Michael T Nurmohamed ${ }^{1,2}$ and Ben AC Dijkmans ${ }^{1,2}$
}

\begin{abstract}
1Department of Rheumatology, VU University Medical Centre, De Boelelaan 1117, 1081 HV Amsterdam, The Netherlands
${ }^{2}$ Department of Rheumatology, Jan van Breemen Institute, Dr Jan van Breemenstraat 2, 1056 AB Amsterdam, The Netherlands
\end{abstract}

Corresponding author: Michael T Nurmohamed, mt.nurmohamed@vumc.nl

Published: 19 September 2008

This article is online at http://arthritis-research.com/content/10/5/118

(C) 2008 BioMed Central Ltd
Arthritis Research \& Therapy 2008, 10:118 (doi:10.1186/ar2491)

The synthetic DMARDs that are commonly used include methotrexate, sulfasalazine, leflunomide and hydroxychloroquine. Several combination therapies with these drugs have been studied, and some of these investigations suggest that combination therapy is superior to monotherapy whereas other studies do not [3].

Two trials in early-RA patients indicated a superior efficacy when corticosteroids, in a step-down approach, are included in the combination therapy. In one investigation the combination sulfasalazine, methotrexate, hydroxychloroquine and lowdose prednisolone was compared with sulfasalazine alone, which could be replaced by methotrexate [4]. The clinical results showed the remission rate after 2 years to be twice as high in the combination group in comparison with the sulfasalazine-alone group. Clinical improvement was also in favour of the combination group. In the other trial, the combination sulfasalazine, methotrexate and initially highdose prednisolone (COBRA scheme) was compared with sulfasalazine treatment alone (COBRA trial) [5]. Prednisolone and methotrexate were tapered and stopped after 28 weeks and 40 weeks, respectively. This investigation was also in favour of the combined treatment group. Together these two studies indicate that the initial addition of corticosteroids improves the clinical efficacy and might have long-term structural benefits [6].

Another major step forward in the treatment of RA (and other inflammatory arthritis diseases) was the introduction of biologics. The first class of biologic drugs that came available were the TNF $\alpha$-blockers infliximab, etanercept and adalimumab, and the recombinant human IL-1 receptor antagonist anakinra [7]. TNF $\alpha$-blockers are clinically as effective as methotrexate but with a much faster onset of action. Anakinra appears to be significantly less potent than TNF $\alpha$-blockers,

DMARD = disease-modifying antirheumatic drug; $\mathrm{LL}=$ interleukin; $\mathrm{RA}=$ rheumatoid arthritis; TNF $=$ tumour necrosis factor. 
and three other classes of drugs have emerged recently as (potential) treatment options: rituximab, an anti-CD20 antibody; abatacept, a costimulation inhibitor; and tocilizumab, an anti-IL-6 receptor [8].

With the introduction of biologics the question arises of whether these - far more expensive - drugs are more effective than synthetic DMARDs. This topic was recently addressed in a well-designed systematic review of the currently available synthetic DMARDs and biologic agents [9]. A total of 143 articles reporting on 101 studies were included in this review. Three trials were identified comparing the efficacy of TNF $\alpha$ blockade and methotrexate in methotrexate-naïve RA patients [10-12].

Etanercept monotherapy was compared with methotrexate in a trial with 632 early-RA patients who were either treated with etanercept twice weekly (10 mg, $n=208$, or $25 \mathrm{mg}, n=207$ ) or with methotrexate once weekly (up to $20 \mathrm{mg} /$ week, $n=217$ ) [10]. At 12 months, 72\% of the $25 \mathrm{mg}$ etanercepttreated group and $65 \%$ of the methotrexate-treated group had an American College of Rheumatology 20 response $(P=0.62)$. There were only very modest radiological deteriorations in these two treatment groups of 1.0 Sharp units and 1.6 Sharp units, respectively (the Sharp scale measures bony erosion and joint space narrowing, and the scale ranges from 0 to 398). In another trial the combination of etanercept with methotrexate (up to $20 \mathrm{mg} /$ week) was compared with treatment with the two drugs alone, in patients with a mean disease duration of up to 7 years, and demonstrated superior efficacy of the combination, whereas there were no relevant differences between the two separate drugs [11]. A similar trial in which adalimumab with or without methotrexate was compared with methotrexate in 799 early-RA patients revealed comparable results [12].

Altogether these three trials indicate no clinically significant differences between monotherapy biologics (that is, adalimumab and etanercept) and methotrexate, whereas the combination of these drugs appears to be clinically (confirmed by a recent meta-analysis [13]) as well as radiologically superior to methotrexate monotherapy. Whether this small difference in radiological scores ultimately results in clinically significant differences in disability remains to be proven - although a recent trial in early-RA patients demonstrated a difference $>2$ Sharp units in favour of 1-year etanercept/methotrexate combination therapy versus methotrexate monotherapy [14], which might be clinically significant when extrapolated to 5 years or more [15].

Nevertheless, the methotrexate dose in the above-mentioned studies was limited to a maximum $20 \mathrm{mg} /$ week, which is sometimes considered too low since doses up to 25-30 mg/week might be used in clinical practice before methotrexate is considered a treatment failure. This clearly further limits the conclusions that can be drawn when addressing the (radiological) efficacy of TNF $\alpha$-blocking agents versus methotrexate from the currently available investigations.

The number of therapeutic drug options for the treatment of RA has increased substantially during the past decades, and it has become clear that antirheumatic treatment should start as soon as possible in patients presenting with RA - but the question remains of what is the best therapeutic strategy in these early RA patients as well as the choice of the first antirheumatic agent. These questions are partially addressed in the BeSt (Dutch acronym for Behandel-Strategieën treatment strategies) study, a randomized clinical trial in 508 earlyRA patients where four commonly used treatment strategies were compared: sequential monotherapy, step-up combination therapy, initial combination therapy with methotrexate with tapered high-dose prednisone, or the TNF antagonist infliximab combined with methotrexate [16]. Treatment adjustments were made every 3 months to achieve low disease activity. This BeSt trial revealed that both initial combination therapies resulted in earlier functional improvement and less radiographic damage after 1 year than did sequential monotherapy or step-up combination therapy. The radiological difference was sustained at 2 years [17].

The conclusion from the BeSt study is that, with intensive and objective monitoring of disease activity and adjustments of therapy, low disease activity is a realistic goal that can be achieved with all treatment strategies. The BeSt authors conclude after 2 years of the BeSt trial that initial combination treatment with tapered high-dose prednisone, methotrexate and sulfasalazine or initial combination treatment with infliximab and methotrexate seems the best choice to rapidly achieve this goal in patients with active RA of recent onset. As indicated by O'Dell, however, the costs of the strategies varied substantially between the groups and, as the clinical results for all groups were comparable at 2 years of therapy, one may argue to start with a single synthetic DMARD with escalation to biologics only in patients with persistent active disease. To address this essential issue, it is necessary to take into account not only the costs related to joint damage but also the loss of productivity and quality of life and other potential consequences of a delay in starting therapy with combined synthetic and biologic drugs [18]. Such data are not yet available, but preliminary evidence indeed indicates that the use of biologics is associated with less work loss and with improved productivity.

On the basis of the present evidence it therefore cannot be concluded definitively that biologics are more clinically effective than synthetic DMARDs, although a radiological difference in favour of biologics is plausible. What should therefore be done in clinical practice? The available literature points towards a combination of synthetic DMARDs (with initial corticosteroids) instead of a biologic as a first treatment choice for patients with early RA, particularly when costeffectiveness issues are also considered $[18,19]$. Moreover, a 
synthetic DMARD combination is preferred over DMARD monotherapy as there is increasing evidence of a window of opportunity in patients with early RA in which the antirheumatic therapy should be as intense as possible, also indicating a need for early identification of these patients. When low disease activity is not reached, treatment should be switched to another strategy.

From the available literature, final conclusions about the longterm safety - particularly malignancies and other rare serious adverse event of biologics - cannot be reached, and largescale observational investigations are obviously needed to address these risks.

It is relevant to realize that nowadays disease remission, rather than low disease activity, should be the treatment target [20].

Recent data from the BeSt investigation reveal that, after 5 years of treatment, remission could be reached in $48 \%$ of all patients and $19 \%$ of patients achieved drug-free remission [21]. This latter finding is important as it might render biologic therapy more cost-effective.

Finally, further research should unravel biomarkers that can identify those patients who will receive most benefit from a particular treatment strategy, and such studies are currently ongoing [22].

\section{Competing interests}

The author declares that they have no competing interests.

\section{References}

1. Weinblatt ME, Coblyn JS, Fox DA, Fraser PA, Holdsworth DE, Glass DN, Trentham DE: Efficacy of low-dose methotrexate in rheumatoid arthritis. N Engl J Med 1985, 312:818-822.

2. O'Dell JR: Treating rheumatoid arthritis early: a window of opportunity? Arthritis Rheum 2002, 46:283-285.

3. Smolen JS, Aletaha D, Keystone E: Superior efficacy of combination therapy for rheumatoid arthritis: fact or fiction? Arthritis Rheum 2005, 52:2975-2983.

4. Möttönen T, Hannonen P, Leirisalo-Repo M, Nissilä M, Kautiainen $\mathrm{H}$, Korpela $\mathrm{M}$, Laasonen L, Julkunen $\mathrm{H}$, Luukkainen $\mathrm{R}$, Vuori $\mathrm{K}$, Paimela L, Blåfield H, Hakala M, Ilva K, Yli-Kerttula U, Puolakka K, Järvinen P, Hakola M, Piirainen H, Ahonen J, Pälvimäki I, Forsberg $\mathrm{S}$, Koota K, Friman C: Comparison of combination therapy with single-drug therapy in early rheumatoid arthritis: a randomised trial. FIN-RACo trial group. Lancet 1999, 353:1568-1573.

5. Boers M, Verhoeven AC, Markusse HM, van de Laar MA, Westhovens R, van Denderen JC, van Zeben D, Dijkmans BA, Peeters AJ, Jacobs $P$, van den Brink HR, Schouten HJ, van der Heijde DM, Boonen A, van der Linden S: Randomised comparison of combined step-down prednisolone, methotrexate and sulphasalazine with sulphasalazine alone in early rheumatoid arthritis. Lancet 1997, 350:309-318.

6. Landewé RB, Boers M, Verhoeven AC, Westhovens R, van de Laar MA, Markusse HM, van Denderen JC, Westedt ML, Peeters AJ, Dijkmans BA, Jacobs P, Boonen A, van der Heijde DM, van der Linden S: COBRA combination therapy in patients with early rheumatoid arthritis: long-term structural benefits of a brief intervention. Arthritis Rheum 2002, 46:347-356.

7. Furst DE, Breedveld FC, Kalden JR, Smolen JS, Burmester GR, Bijlsma JW, Dougados M, Emery P, Keystone EC, Klareskog L, Mease PJ: Updated consensus statement on biological agents, specifically tumour necrosis factor $\alpha$ (TNF $\alpha$ ) blocking agents and interleukin-1 receptor antagonist (IL-1 ra), for the treatment of rheumatic diseases, 2005. Ann Rheum Dis 2005, 64(Suppl 4):iv2-iv14.

8. Smolen JS, Aletaha D, Koeller M, Weisman MH, Emery P: New therapies for treatment of rheumatoid arthritis. Lancet 2007 , 370:1861-1874.

9. Donahue KE, Gartlehner G, Jonas DE, Lux $\sqcup$, Thieda P, Jonas BL, Hansen RA, Morgan LC, Lohr KN: Systematic review: comparative effectiveness and harms of disease-modifying medications for rheumatoid arthritis. Ann Intern Med 2008, 148:124-134.

10. Bathon JM, Martin RW, Fleischmann RM, Tesser JR, Schiff MH, Keystone EC, Genovese MC, Wasko MC, Moreland LW, Weaver AL, Markenson J, Finck BK: A comparison of etanercept and methotrexate in patients with early rheumatoid arthritis. N Engl J Med 2000, 343:1586-1593.

11. Klareskog L, van der Heijde D, de Jager JP, Gough A, Kalden J, Malaise M, Martín Mola E, Pavelka K, Sany J, Settas L, Wajdula J, Pedersen R, Fatenejad S, Sanda M: TEMPO (Trial of Etanercept and Methotrexate with Radiographic Patient Outcomes) study investigators. Therapeutic effect of the combination of etanercept and methotrexate compared with each treatment alone in patients with rheumatoid arthritis: double-blind randomised controlled trial. Lancet 2004, 363:675-681.

12. Breedveld FC, Weisman MH, Kavanaugh AF, Cohen SB, Pavelka K, van Vollenhoven R, Sharp J, Perez JL, Spencer-Green GT: The PREMIER study: a multicenter, randomized, double-blind clinical trial of combination therapy with adalimumab plus methotrexate versus methotrexate alone or adalimumab alone in patients with early, aggressive rheumatoid arthritis who had not had previous methotrexate treatment. Arthritis Rheum 2006, 54:26-37.

13. Alonso-Ruiz A, Pijoan Jl, Ansuategui E, Urkaregi A, Calabozo M, Quintana A: Tumor necrosis factor alpha drugs in rheumatoid arthritis: systematic review and metaanalysis of efficacy and safety. BMC Musculoskelet Disord 2008, 17:52.

14. Emery $P$, Breedveld FC, Hall S, Durez $P$, Chang DJ, Robertson D, Singh A, Pedersen RD, Koenig AS, Freundlich B: Comparison of methotrexate monotherapy with a combination of methotrexate and etanercept in active, early, moderate to severe rheumatoid arthritis (COMET): a randomised, double-blind, parallel treatment trial. Lancet 2008, 372:375-382.

15 van der Heijde D, Landewé R, van Vollenhoven R, Fatenejad S, Klareskog $L$ : Level of radiographic damage and radiographic progression are determinants of physical function: a longitudinal analysis of the TEMPO trial. Ann Rheum Dis 2008, 67: 1267-1270.

16. Goekoop-Ruiterman YP, de Vries-Bouwstra JK, Allaart CF, van Zeben D, Kerstens PJ, Hazes JM, Zwinderman AH, Ronday HK, Han KH, Westedt ML, Gerards AH, van Groenendael JH, Lems WF, van Krugten MV, Breedveld FC, Dijkmans BA: Clinical and radiographic outcomes of four different treatment strategies in patients with early rheumatoid arthritis (the BeSt study): a randomized, controlled trial. Arthritis Rheum 2005, 52:33813390.

17. Goekoop-Ruiterman YP, de Vries-Bouwstra JK, Allaart CF, van Zeben D, Kerstens PJ, Hazes JM, Zwinderman AH, Peeters AJ, de Jonge-Bok JM, Mallée C, de Beus WM, de Sonnaville PB, Ewals $\mathrm{JA}$, Breedveld FC, Dijkmans BA: Comparison of treatment strategies in early rheumatoid arthritis: a randomized trial. Ann Intern Med 2007, 146:406-415.

18. O'Dell JR: The BeSt way to treat early rheumatoid arthritis? Ann Intern Med 2007, 146:459-460.

19. Nurmohamed MT, Dijkmans BA: Efficacy, tolerability and cost effectiveness of disease-modifying antirheumatic drugs and biologic agents in rheumatoid arthritis. Drugs 2005, 65:661-694.

20. Grigor C, Capell H, Stirling A, McMahon AD, Lock P, Vallance R, Kincaid W, Porter D: Effect of a treatment strategy of tight control for rheumatoid arthritis (the TICORA study): a singleblind randomised controlled trial. Lancet 2004, 364:263-269.

21. Klarenbeek NB, Güler-Yüksel M, van der Kooij SM, van der Heijde DMFM, Huizinga TWJ, Kerstens PJSM, Peeters AJ, Ronday HK, Westedt ML, Dijkmans BAC, Allaart CF: Clinical outcomes of four different treatment strategies in patients with recentonset rheumatoid arthritis: 5-years results of the BeSt-study [abstract]. Ann Rheum Dis 2008, 67(Suppl II):187.

22. Nederlands Trial Register [http://www.trialregister.nl/trialreg/ admin/rctview.asp?TC=1213] 